\title{
Effects of microhabitat on recruitment variation in a Gulf of Maine reef fish*
}

\author{
Phillip S. Levin \\ Department of Zoology and Center for Marine Biology, University of New Hampshire, Durham, New Hampshire 03824, USA
}

\begin{abstract}
Variation in recruitment of larvae can be important in determining temporal and spatial variation in adult demersal fish populations. This study examines how microhabitat use by newly settled cunner Tautogolabrus adspersus (Pisces: Labridae) influences small-scale recruitment variation. The microhabitat occupied by cunner recruits was characterized by quantifying 14 attributes of the microhabitat at 2 sites in Southern Maine, USA. Attributes at randomly selected sites were also recorded. Cunner recruits were distributed nonrandomly among microhabitats within sites. Recruit presence was positively associated with the presence of macrophytes and negatively associated with microhabitats of low structural complexity. Association with specific microhabitats differed among sites; however, microhabitats available also differed among sites. While presence or absence could be predicted by attributes of microhabitats, small-scale densities of fish could not. These data suggest that microhabitat use is nonrandom, and that the distribution of microhabitat types may influence small scale spatial patterns of recruitment in this species.
\end{abstract}

\section{INTRODUCTION}

Most demersal marine fishes are characterized by a complex life cycle consisting of a dispersive pelagic larval phase followed by a relatively site-attached adult phase. In these species, pronounced variation in the settlement of larvae to the adult population can be important in determining patterns of distribution and abundance in demersal fish populations (Doherty 1981, 1983, Victor 1986, Mapstone \& Fowler 1988; but see Jones 1987, Forrester 1990). Because settlement has been difficult to measure directly, most workers have measured recruitment (the first sighting in the adult habitat of a settled juvenile) (Richards \& Lindeman 1987). Since patterns of recruitment can directly affect patterns of distribution and abundance, an understanding of the importance of factors that contribute to recruitment variation is critical to the comprehension of the dynamics of demersal fish populations.

Variation in recruitment may be affected by the sup-

\footnotetext{
- Contribution no. 239 from the University of New Hampshire Center for Marine Biology
}

ply of pelagic larvae and post-larvae competent to settle (i.e. move from the water column to the demersal habitat) (Cowen 1985, Olson 1985, Gaines et al. 1985), the behavior of larvae as they settle (Sweatman 1985), and early post-settlement mortality and growth (Jones 1987. Forrester 1990). Each of these factors may be influenced by the structure of the demersal habitat at various spatial or temporal scales. Water transport to different topographic features (for example bays versus headlands) varies, influencing the supply of larvae arriving at a site (Ebert \& Russell 1988). On a small scale, habitat features can increase or reduce larval density by altering the local hydrographic regime (Eckman 1987).

The behavior of pre- and post-settlement fish as well as post-settlement demography can also be affected by habitat characteristics (Marliave 1977, Sale et al. 1984, Schulman 1984, Jones 1988, Carr 1989, Hixon \& Beets 1989). The quality and/or number of refuges from predation vary with habitat structure (Orth et al. 1984, Behrents 1987); consequently, settling individuals suffer lower mortality in habitats with more or higher quality shelter (Schulman 1984, Hixon \& Beets 1989). Prey availability may also vary with habitat (Werner et 
al. 1983, Holbrook \& Schmitt 1988) affecting growth rates of settlers and ultimately recruitment success.

Assemblages of macrophytes are important features of nearshore demersal habitats in the Gulf of Maine (Chapman \& Johnson 1990). The species composition, dispersion and structural complexity of these algal communities vary both spatially and temporally (Mathieson \& Hehre 1986, Chapman \& Johnson 1990). At a very coarse level there are 2 community types which dominate shallow rocky substrata (Witman 1987. Johnson \& Mann 1988). These are sea urchin Strongylocentrotus droebachiensis dominated areas (sensu Schiel \& Foster 1986), in which encrusting coralline algae dominate the macrophyte assemblage, and seaweed beds dominated by lamanarian kelps with a diverse understory of red algae.

Kelp beds are more productive habitats than urchin dominated areas (Mann 1972), and support rich populations of juvenile fishes (reviewed by Wheeler 1980). Ephemeral patches of macroalgae are common in urchin dominated areas (Himmelman \& Nedelec 1990), and also support aggregations of juvenile fish (pers. obs.). The association of juvenile fish with vegetation appears primarily to be a response to prey availability and the acquisition of refuges from predation (Holbrook \& Schmitt 1988). However, the degree to which temperate fish recruits associate with patches of specific macrophytes or other microhabitat attributes has not been investigated.

In this paper, the use of microhabitats by recruits of a common labrid fish is examined within an urchin dominated area and a kelp bed. Emphasis is placed on macrophytes since they are prominent features of the habitats investigated. Specifically, the null hypothesis that recruitment occurs at random with respect to microhabitat characteristics is tested in both habitats.

\section{METHODS}

Study species. Cunner Tautogolabrus adspersus (Labridae) are prominent members of rocky-reef communities in temperate waters of the western North Atlantic (Bigelow \& Schroeder 1953). T. adspersus spawns during early and mid summer (Dew 1976, Pottle \& Green 1979a). After a larval life averaging 18 to $21 \mathrm{~d}$ (Gleason \& Reschiek in press), fish settle to the demersal habitat. They appear to feed opportunistically on zooplankton and small demersal invertebrates (Chao 1972, Levin unpubl.). Recruits are site-attached and do not stray far from cover (Bigelow \& Schroeder 1953, Pottle \& Green 1979b, Gleason \& Reschiek 1990). The majority of recruitment in the southern Gulf of Maine occurs in July and August (Levin unpubl.).

Study sites. The Gulf of Maine is a semi-enclosed basin bounded on the north and west by New England (USA) and on the east by Nova Scotia (Canada). It is subject to extreme seasonal variability in temperature and nutrient availability (Hopkins \& Garfield 1979, Brooks \& Townsend 1989). The present study was conducted at 2 sites within $100 \mathrm{~m}$ of each other along the southern Maine coast in the vicinity of York, Maine (Fig. 1). Site 1, an urchin dominated area on Cape Neddick, consists primarily of cobble substratum encrusted with crustose coralline algae (Clathromorphum sp., Lithothamnium sp. and Phymatolithon sp.), with foliose algae (Ulva lactuca), filamentous (Ceraminium sp., Polysiphonia sp.) and corticated algae (Desmarestia sp. and Ahnfeltia plicata) distributed throughout. Site 2, on Nubble Island, is predominantly cobble substratum with a macrophyte assemblage consisting primarily of kelps (Lamanaria sacharina, L. digitata and Agarum cribrosum). Depth at mean low water was ca $6.5 \mathrm{~m}$ at both sites.

Sampling methods. Overall densities of cunner recruits at each site were quantified by visually censusing $15 \times 1 \mathrm{~m}$ band transects (Keast \& Harker 1977 . Lincoln-Smith 1988). Replicate transects were randomly placed using triplets of random numbers. The first 2 random numbers represented a compass direction and distance from a haphazard starting point, and the third number indicated the compass heading the transect was extended. A diver on SCUBA extended the transect line and was followed 3 to 5 min later by another diver swimming at a rate of 8 to $10 \mathrm{~m} \mathrm{~min}^{-1}$ The latter diver held a T-shaped bar to delineate the transect width. The 3 to $5 \mathrm{~min}$ interval between extending and sampling the transect was sufficient to allow fish to resume their normal behavior, and thus provided a reliable assessment of the densities of recruits.

On additional transects a detailed analysis of the microhabitat used by each recruit was conducted

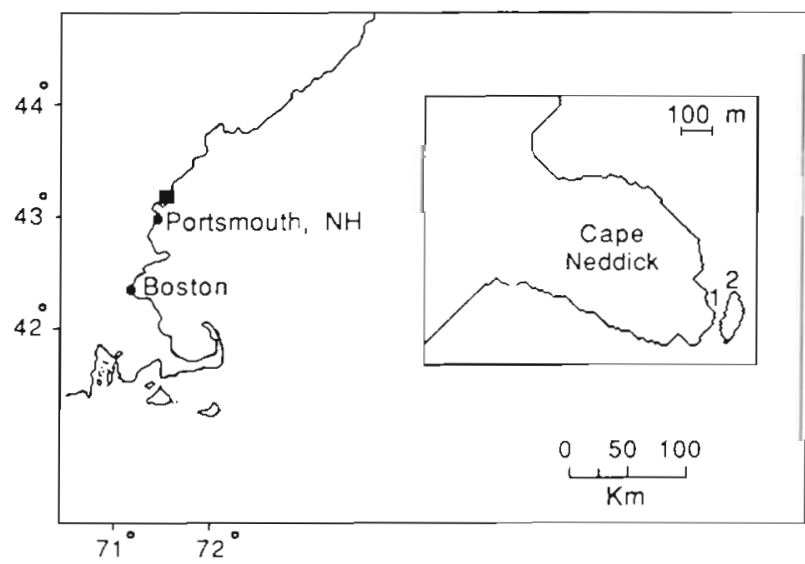

Fig. 1. Study area in the Southern Gulf of Maine showing the locations of both study sites on Cape Neddick, Maine, USA 
Since young juvenile cunner are strongly site-attached, the microhabitat in which they were found was assumed to be the one they used. A $0.25 \mathrm{~m}^{2}$ PVC quadrat was centered over the site occupied by each fish. In each quadrat macrophytes were classified by their morphology as crustose corallines, articulated corallines, filamentous (including corticated macrophytes), foliose or leathery (sensu Littler \& Littler 1980, Steneck \& Watling 1982). Macrophyte percent cover was determined by recording the type of algae under each of 45 points created by a grid of monofilament line strung across the quadrat. In addition, the percent cover of all attached invertebrates was enumerated. The substratum was categorized as sand, rock, cobble, gravel or shell, and the angle of the substratum was categorized as horizontal, sloped, vertical or overhanging. The maximum height of the macrophyte canopy, presence/absence of adult cunner, and the densities of other fish and invertebrates were also recorded. The same microhabitat attributes were measured at 20 randomly selected quadrats at each site. Locations of random quadrats were determined using pairs of numbers to indicate a compass direction and distance from an arbitrary starting point.

A multivariate analysis of variance (MANOVA) was used to test the null hypothesis that quadrats occupied by cunner do not have different microhabitat characteristics to randomly selected quadrats (Green 1980). Significance was determined using Pillai's trace and its $F$ approximation (Wilkinson 1990). Where results of the MANOVA indicated that quadrats occupied by recruits were different from those randomly sampled, univariate $F$ tests were used to identify which microhabitat characteristics were responsible for this difference.

Those microhabitat characteristics which were significant $(p<0.05)$ in the MANOVA were then used as independent variables in linear regression analyses to determine the extent of the within-quadrat variance in fish density explained by these microhabitat attributes (Zar 1984). In all analyses percentage cover data were arcsine transformed and counts were converted to $\log (x+1)$ to normalize the data and homogenize variances (Green 1980, Zar 1984).

\section{RESULTS}

The 2 sites examined differed significantly in the microhabitats available for use by cunner recruits (Pillai Trace $=0.666 ; \mathrm{p}<0.01)$. Site 2 had a greater percentage cover of kelp than Site 1 (30.9 vs $10.2 \%$ ), and had a greater mean algal canopy height (37.9 vs $15.4 \mathrm{~cm}$ ). Variance ratio tests (Zar 1984) indicated that the degree of among quadrat variation in percent cover of crustose coralline, articulated coralline, foliose and leathery algae was not significantly different between sites. However, the variance of filamentous algal percent cover was greater at Site $1(F=4.37$; $\mathrm{p}<0.05)$.

The density of cunner recruits also differed between sites $(t=2.117 ; \mathrm{p}<0.05)$. Site 1 had a mean recruit density of 3.25 ind. $m^{-2}(S E=0.864)$ while Site 2 had a mean of 1.0 ind $\mathrm{m}^{-2}(\mathrm{SE}=0.312)$.

Multivariate analyses of variance indicated that there were significant differences between microhabitats used by cunner recruits and those randomly sampled at both Site 1 (Pillai Trace $=0.327$; $<<0.05$ ) and Site 2 (Pillai Trace 0.393; p<0.05) (Fig. 2). Characteristics of the substratum and the presence of other animals were not important in distinguishing between the randomly sampled microhabitats and those used by the fish. Rather, the nature of the macroalgal assemblage was a good indicator of recruit presence (Table 1). At Site 1, quadrats occupied by recruits were covered, on average, by $24.2 \%$ filamentous algae and $30.3 \%$ foliose algae, whereas randomly sampled quadrats had covers of $15.6 \%$ and $8.89 \%$ of filamentous and foliose algae respectively (Fig. 3). Furthermore, randomly selected microhabitats contained $44.9 \%$ cover of crustose coralline algae and $17.1 \%$ cover of sand versus $23.6 \%$ cover of crustose corallines and $9.8 \%$ cover sand in microhabitats with cunner. Additionally, at this site quadrats with fish tended to have taller algal canopies. Mean canopy height in quadrats with fish was $27.6 \mathrm{~cm}$ compared to $15.4 \mathrm{~cm}$ in randomly sampled sites (Fig. 4)

At Site 2, only algal canopy height was important in distinguishing microhabitats used from those randomly selected (Table 1). As at Site 1, recruits were associated with taller algal canopies with an average algal height of $69.2 \mathrm{~cm}$ in quadrats with cunner recruits versus 37.9 in random quadrats (Fig. 4). Unlike Site 1, no differences were evident in percent covers of conspicuous macroalgae or sand (Fig. 2).

Results of the multivariate analysis of variance demonstrate that microhabitat features influence the presence or absence of recruits, but do not indicate whether the microhabitat characteristics examined are good predictors of recruit abundance. The regression analyses determined the relationship between microhabitat variables and recruit abundance. Independent variables used as predictors were those characteristics important in distinguishing quadrats used by recruits from those randomly sampled. At Site 1, a multiple regression with percent cover of sand, crustose coralline algae, filamentous algae, and foliose algae and algal height as independent variables explained only $2 \%$ of the among-quadrat density of recruits and was not significant $(p \gg 0.05)$. Likewise, at Site 2 , a regression with algal height as an independent variable was not significant $(p \gg 0.05)$ and explained $0.6 \%$ of the 

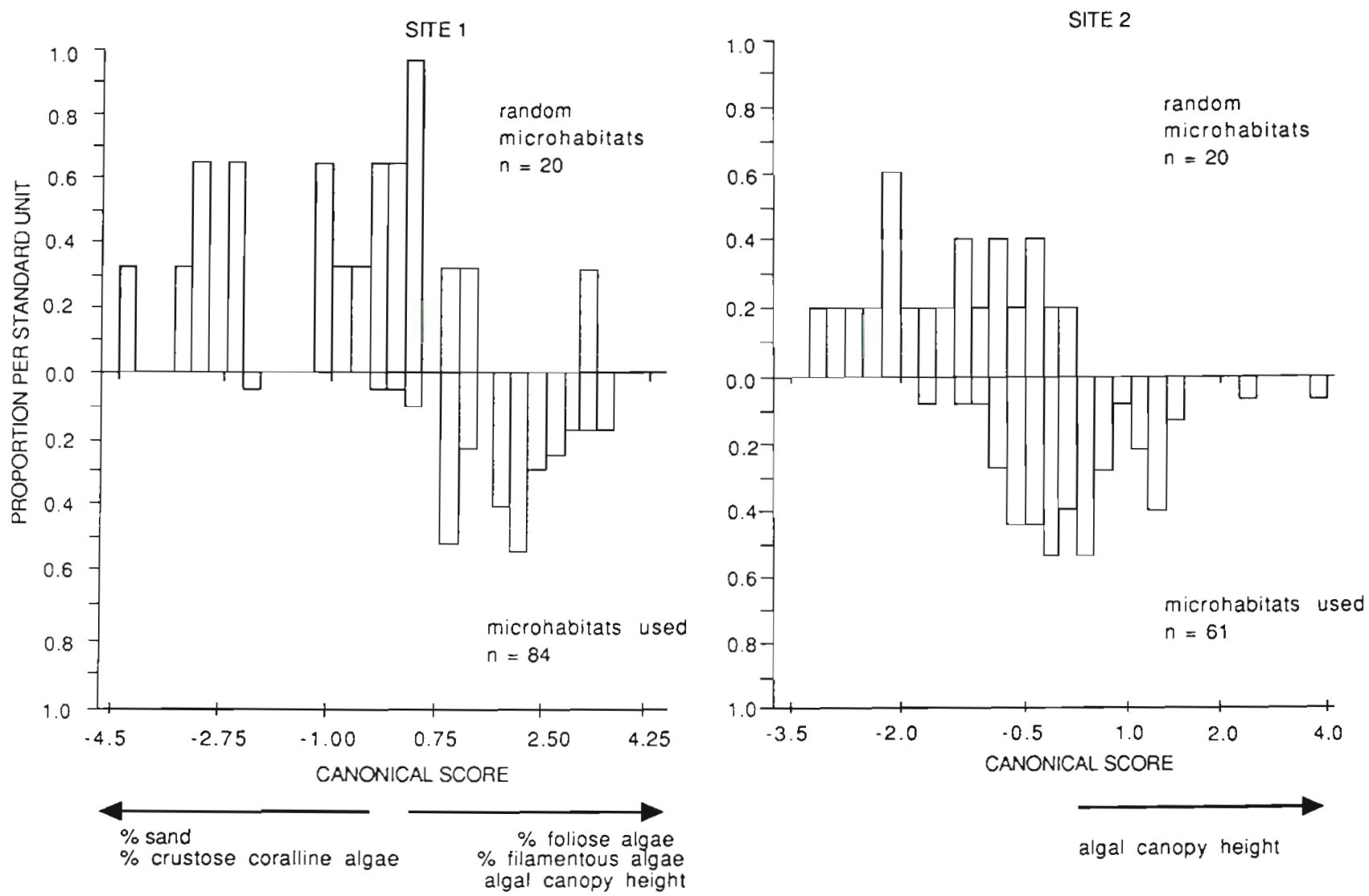

Fig. 2. Proportions of quadrats in each sample associated with each particular canonical score derived from the MANOVA are first standardized (by dividing by the sample standard deviation), then plotted against the canonical score

variance. These negative results show that the microhabitat characteristics important in determining presence or absence of recruits are not significant in explaining variance in recruit density.

Table 1. Results of a multivariate ANOVA testing differences in microhabitat characteristics between quadrats occupied by cunner recruits and those sampled at random. Presented are univariate $F$ tests which test each character separately. Only significant results $(p<0.05)$ are shown

\begin{tabular}{|lrcc|}
\hline Source & df & $F$ & $p$ \\
\hline Site 1 & 1 & 5.905 & 0.02 \\
$\%$ Cover sand & 82 & & \\
$\quad$ Error & 1 & 12.204 & 0.001 \\
\% Cover coralline & 82 & & \\
$\quad$ Error & 1 & 11.059 & 0.001 \\
$\%$ Cover filamentous & 82 & & \\
$\quad$ Error & 1 & 5.391 & 0.023 \\
$\%$ Cover foliose & 82 & & \\
$\quad$ Error & 1 & 7.527 & 0.007 \\
Max. algal height & 82 & & \\
$\quad$ Error & & & \\
Site 2 & 1 & 5.034 & 0.028 \\
Max. algal height & 74 & & \\
$\quad$ Error & & & \\
\hline
\end{tabular}

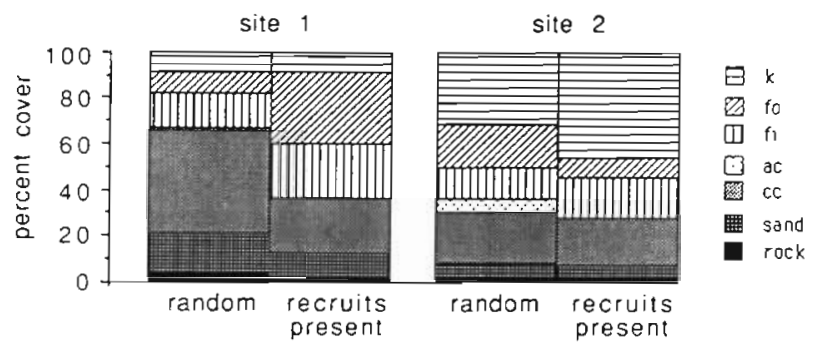

Fig. 3. At Site 1, mean percent macroalgal cover was different in those quadrats occupied by cunner versus randomly sampled quadrats. This difference was not evident at Site 2. (k: kelp, fo: foliose algae, fi: filamentous algae, ac: articulated coralline algae, cc: crustose coralline algae)

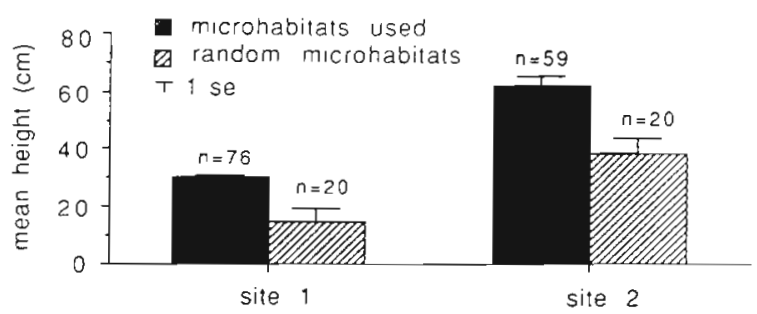

Fig. 4. Difference in maximum algal height between microhabitats with fish present and those randomly selected. Each bar illustrates a mean maximum height with the sample site (number of quadrats) shown above the bar 


\section{DISCUSSION}

Juvenile temperate fish, especially tropical derivatives, are commonly associated with macroalgae (Jones 1984, Ebeling \& Laur 1985, Jones 1988, Carr 1989, DeMartini \& Roberts 1990). The data presented here indicate that recruiting Tautogolabrus adspersus use specific algal microhabitats within broader habitat types. Cunner recruits were associated with tall filamentous and foliose algae in the urchin dominated site and with tall algae in the kelp bed site. Despite this microhabitat association, small-scale variation in abundance could not be explained by microhabitat attributes associated with recruit presence. Therefore, while the presence of fish recruits is associated with these microhabitat features, other factors, such as small-scale variation in larval supply or variability in food availability, contribute to variation in density of fish among algal patches.

How these patterns of recruitment are established is unknown. Habitat selection by settling larvae, differential post-settlement survivorship or movements of individuals among patches could produce the observed recruitment patterns. In laboratory experiments Marliave (1977) showed that several species of settling fish exhibited substratum preferences. Thus, recruitment patterns may reflect microhabitat selection by settling larvae. Sale et al. (1984) showed microhabitat selection by newly settled coral reef fish in the field; however, they did not determine if differential post-settlement mortality is reflected in subsequent patterns of recruitment. In the Gulf of Maine, it is possible that microhabitat selection by settling cunner larvae occurs; however, the effects of microhabitat selection on the distribution of recruits would be most evident if preferred patches were separated by expanses of undesirable habitat making demersal migration among desirable patches less likely

Settlement may also occur randomly with respect to microhabitat but with highest survivorship in microhabitats with dense macroalgal cover. For those individuals which recruit to urchin dominated areas where macroalgal cover is very patchy, random settlement may expose individuals occurring on crustose coralline patches to higher rates of predation than those in patches of fleshy macrophytes. Indeed, the sculpin Myoxocephalus aeneus is abundant in urchin dominated areas, and has been observed preying on cunner recruits in high numbers. Kelp bed habitats are less heterogeneous than urchin dominated areas and differences in predation rates among microhabitats may be of less importance than in urchin dominated areas.

The relative homogeneity of kelp beds makes movement of newly settled fish among microhabitats more likely than in urchin domirated areas. Individuals moving in kelp beds would maintain contact with algal cover while those migrating among discrete macrophyte patches in urchin dominated zones would have to cross expanses of barren habitat. It is clear that further work is needed in this area. It seems likely that the relative importance of habitat selection by larvae, differential post-settlement survivorship and movement will change as the nature of the habitat changes.

The composition of the macrophyte assemblage as well as the persistence of the assemblage may influence the ways in which settlement patterns are generated and subsequently altered. In urchin dominated areas where the distribution of preferred microhabitats for juvenile fish is patchy (Schiel \& Foster 1986, Himmelman \& Nedelec 1990, Levin unpubl.), responses by fish to attributes of patch structure may assume greater significance than in more uniform habitats such as kelp beds (Weins 1976). For example, aggregations of erect algal species in urchin dominated zones may produce clumped patterns of dispersion of juvenile fish which associate with algae (Jones 1984, Levin unpubl.). Consequently, behavioral and ecological processes which are density dependent at this spatial scale may occur more readily than in habitats where algae are distributed in a random or uniform fashion

The relative importance of larval supply, settlement and post-recruitment processes in determining the dynamics of demersal fish populations is a matter of much debate. The data presented herein show cunner recruits use specific microhabitats within broader habitat types. The close association of recruits with specific microhabitats suggests that variation of the spatial patterning of this resource can have profound influences on the small-scale dynamics of these populations (Addicott et al. 1987). This study as well as others (Jones 1984, Ebeling \& Laur 1985, Keats et al. 1987, Carr 1989) has shown that many juvenile temperate fishes associate with macroalgae; however, it is evident that experimental analyses are needed assessing how spatial patterning of macrophyte assemblages influence pre- and postrecruitment processes.

Acknowledgements. I thank P. F. Sale, G. E. Forrester, R. R. Olson and anonymous reviewers and for their helpful comments on the manuscript. A. Armstrong, T. Campbell, G. E. Forrester, M. J. James, K. Gestring, J. Guy, L. G. Harris, W. Lambert, P. F. Sale, and K. Verney provided diving assistance. I am grateful for the advice of P. F. Sale, G. E. Forrester, T. P. Good, L. G. Harris, D. A. Levin, M. J. Levin and R. R. Olson. Funding was provided by the Lerner-Gray Fund for Marine Research of the American Museum of Natural History, a Grant-in-Aid from Sigma Xi, The Scientific Research Society and a grant from the University of New Hampshire Central Research Fund. 


\section{LITERATURE CITED}

Addicott, J. F., Aho, J. F., Antolin, M. F., Padilla, D. K., Richardson, J. S., Soluk, D. A. (1987). Ecological neighborhoods: scaling environmental patterns. Oikos 49: 340-346

Behrents, K. C. (1987). The influence of shelter availability on recruitment and early survivorship of Lythrypnus dalli Gilbert (Pisces: Gobiidae). J. exp. mar. Biol. Ecol. 107: 45-59

Bigelow, H. B., Schroeder, S. C. (1953). Fishes of the Gulf of Maine. Fishery Bulletin of the Fish and Wildlife Service. Vol. 53. U.S. Government Printing Office, Washington

Brooks, D. A. Townsend, D. W. (1989). Variability of the coastal current and nutrient pathways in the eastern Gulf of Maine. J. mar Res. 47: 303-321

Carr, M. H. (1989). Effects of macroalgal assemblages on the recruitment of temperate zone reef fishes. J. exp. mar. Biol. Ecol. 126: 59-76

Chao, L. N. (1972). Digestive system and feeding habitats of the cunner, Tautogolabrus adspersus, a stomachless fish. Fish. Bull. U. S. 71: 565-586

Chapman, A. R. O., Johnson, C. R. (1990). Disturbance and organization of macroalgal assemblages in the Northwest Atlantic. Hydrobiologia 192: 77-121

Cowen, R. K. (1985). Large scale pattern of recruitment by the labrid, Semicossyphus pulcher: causes and implications. J. mar. Res. 43: 719-742

DeMartini, E. E., Roberts, D. A. (1990). Effects of giant kelp (Macrocystis) on the density and abundance of fishes in a cobble-bottom kelp forest. Bull. mar. Sci. 46: 287-300

Dew, C. A. (1976). A contribution to the life history of the cunner, Tautogolabrus adspersus in Fishers Island Sound, Connecticut. Chesapeake Sci. 17: 101-113

Doherty, P. J. (1981). Coral reef fishes: recruitment limited assemblages? Proc. 4th int. Coral Reef Symp. (Manilla) 2 $465-470$

Doherty, P. J. (1983). Tropical territorial damselfishes: is density limited by aggression or recruitment? Ecology 64 $176-190$

Ebeling, A. W., Laur, D. R. (1985). The influence of plant cover on surfperch abundance at an offshore temperate reef Environ. Biol. Fish. 12: 169-179

Ebert, T. A., Russell, M. P. (1988). Latitudinal variation in size structure of the west coast purple sea urchin: a correlation with headlands. Limnol. Oceanogr. 33: 286-294

Eckman, J. E. (1987). The role of hydrodynamics in recruitment, growth, and survival of Argopecten irradians (L.) and Anomia simplex (D'Orbigny) within eelgrass meadows. J exp. mar. Biol. Ecol. 106: 165-191

Forrester, G. E. (1990). Factors influencing the juvenile demography of a coral reef fish. Ecology 71. 1666-1681

Gaines S., Brown, S., Roughgarden, J. (1985). Spatial variation in larval concentrations as a cause of spatial variation in settlement for the barnacle, Balanus glandula. Oecologia 65: $267-272$

Gleason, T R., Recksiek, C. W. (1990). Preliminary field verification of daily growth increments in the lapillar otoliths of juvenile cunner Am. Fish. Soc. Symp. Vol. 7, p. 562-565

Green, R. H. (1980). Multivariate approaches in ecology: the assessment of ecologic similarity. Ann. Rev. Ecol. Syst. 11 $1-14$

Himmelman, J. H., Nedelec, H. (1990). Urchin foraging and algal survival strategies in intensely grazed communities in Eastern Canada. Can. J. Fish. Acuat. Sci. 47: 1011-1026

Hixon, M. A., Beets, J. P. (1989). Shelter characteristics and Caribbean fish assemblages: experiments with artificial reefs. Bull. mar Sci. 44:666-680
Holbrook, S. J., Schrnitt, R. J. (1988). The combined effects of predation risk and food reward on patch selection. Ecology 69: $125-134$

Hopkins, T. S., Garfield, N (1979). Gulf of Maine Intermediate Water. J. mar Res. 37: 103-139

Johnson, C. R., Mann, K. H. (1988). Diversity, patterns of adaptation and stability of Nova Scotian kelp beds. Ecol. Monogr 58: 129-154

Jones, G. P. (1984). The influence of habitat and behavioural interactions on the local distribution of the wrasse Pseudolabrus celidotus. Environ. Biol. Fish. 10: 43-58

Jones, G. P. (1987). Competitive interactions among adults and juveniles in a coral reef fish. Ecology 68: 1534-1547

Jones, G. P. (1988). Ecology of rocky reef fish of north-eastern New Zealand: a review. N. Z. J. mar. Freshwat. Res. 22: $445-462$

Keast, A., Harker, J. (1977). Strip counts as a means of determining densities and habitat utilization patterns in lake fishes. Environ. Biol. Fish. 1: 181-188

Keats, D. W., Steele, D. H., South, G. R. (1987). The role of fleshy macroalgae in the ecology of juvenile cod (Gadus morhua L.) in inshore waters off eastern Newfoundland. Can. J Zool. 65: 49-53

Lincoln Smith, M. P. (1988). Effects of observer swimming speed on sample counts of temperate rocky reef fish assemblages. Mar Ecol. Prog. Ser. 43: 223-231

Littler, M. M., Littler, D. S. (1980). The evolution of thallus form and survival strategies in benthic marine macroalgae: field and laboratory test of a functional form model. Am. Nat. 116: 25-44

Mann, K. H. (1972). Ecological energetics of the sea-weed zone in a marine bay on the Atlantic coast of Canada. II. Productivity of the seaweeds. Mar. Biol. 14: 199-209

Mapstone B. D., Fowler, A. J. (1988). Recruitment and the structure of assemblages of fish on coral reefs. Trends Ecol. Evol. 3: 72-77

Marliave, J. B. (1977). Substratum preferences of settling larvae of marine fishes reared in the laboratory. J. exp. mar. Biol. Ecol. 27: 47-60

Mathieson, A. C., Hehre, E. J. (1986). A synopsis of New Hampshire seaweeds. Rhodora 88: 1-139

Olson, R. R. (1985). The consequences of short-distance larval dispersal in a sessile marine invertebrate. Ecology 66: 30-39

Orth, R. J., Heck, K. L., Van Montfrans, J. V (1984). Faunal communities in seagrass beds: a review of the influence of plant structure and prey charactersitics on predator-prey relationships. Estuaries $7 \cdot 339-350$

Pottle, R. A., Green, J. M. (1979a). Field observations on the reproductive behavior of the cunner in Newfoundland. Can. J. Zool. 57.247-256

Pottle, R. A., Green, J. M. (1979b). Territorial behavior of the north temperate labrid, Tautogolabrus adspersus. Can J. Zool. 57: 2337-2347

Richards, W J., Lindeman, K. C. (1987). Recruitment dynamics of reef fishes: planktonic processes, settlement and demersal ecologies, and fisheries analysis. Bull. mar. Sci. $41.397-410$

Sale, P. F., Douglas, W A., Doherty, P. J. (1984). Choice of microhabitats by coral reef fishes at settlement. Coral Reefs 3: 91-99

Schiel, D. R., Foster, M. S. (1986). The structure of subtidal algal stands in temperate waters. Oceanogr mar Biol. A. Rev. 24: 265--307

Schulman, M. J. (1984). Resource limitation and recruitment patterns in a coral reef fish assemblage. J. exp. mar Biol Ecol. 74: 85-109 
Steneck, R. S., Watling, L. (1982). Feeding capabilities and limitations of herbivorous molluscs: a functional group approach. Mar Biol. 68: 299-319

Sweatman, H. P. A. (1985). The influence of adults of some coral reef fishes on larval recruitment. Ecol. Monogr. 55: 469-485

Victor, B. C. (1986). Larval settlement and juvenile mortality in a recruitment-limited coral reef population. Ecol. Monogr 56: $145-160$

Werner, E. E., Gilliam, J. F., Hall, D. J., Mittelbach, G. G (1983). An experimental test of the effects of predation risk on habitat use in fish. Ecology 64: 1540-1548

Wheeler, A. (1980). Fish-algal relations in temperate waters.

This article was submitted to the editor
In: Price, T H., Irvine, D. E. G., Farnham, W. F. (eds.) The shore environment, Vol. 2, Ecosystems. Academic Press, London, p. 677-698

Wiens, J. A. (1976). Population responses to patchy environments. Ann. Rev. Ecol. Syst. 7 . 81-120

Wilkinson, L. (1990). SYSTAT the system for statistics. SYSTAT, Inc. Evanston

Witman, J. D. (1987). Subtidal coexistence: storms, grazing, mutualism, and the zonation of kelps and mussels. Ecol. Monogr 57: 167-187

Zar, J. H. (1984). Biostatistical analysis. Prentice-Hall, Inc., Englewood Cliffs

Manuscript first received: November 6, 1990 Revised version accepted: May 29, 1991 